\title{
The Debacle of Satyam Computers Ltd: A Case Study from Management's Perspective
}

\author{
Amna Niazi ${ }^{1, *}$, Muhammad $\mathrm{Ali}^{2}$ \\ ${ }^{1}$ Department of Humanities, Management and Social Sciences, University of Engineering \& Technology, Pakistan \\ ${ }^{2}$ Department of Management Studies, National University of Computer and Emerging Sciences, Pakistan
}

Copyright (C) 2015 Horizon Research Publishing All rights reserved.

\begin{abstract}
Corporate accounting fraud is not a new thing in this world after the debacle of Enron, which proved to be a stimulus for others to fancy their own Enron in their respective organizations. This started a series of events related to corporate financial crimes. With increasing trend in financial crimes across the globe, investors lost their confidence, the credibility of financial disclosures were being questioned and companies were facing huge financial losses. Satyam Computers Ltd was just another case featuring almost same causes like that of Enron and others including WorldCom. Satyam computers were once the crown jewel of Indian IT industry, but were brought to the ground by its founders in 2009 as a result of financial crime. The debacle of Satyam raised a debate about the role of CEO in driving an organization to the heights of success and its relation with the board members and core committees. The scam at Satyam brought to the light the role of corporate governance in shaping the protocols related to the working of audit committee and duties of board members. Thus, an in depth study is conducted to analyze the financial scam from a management's perspective.
\end{abstract}

Keywords Debacle, Satyam Computers, Accounting Fraud, Case Study, Corporate Governance, Management's Perspective

\section{Introduction}

From the past several decades, the fraudulent activities within organizations were at their peak until serious efforts were taken after the emergence of fraud in the Enron case. The issue raised serious questions about the integrity and credibility of the executives and decision making authorities which brought the government to take legislative steps in order to prevent such kind of incident to happen in the future and make authorities accountable for their actions. Enron being the benchmark in the public limited companies, rose many questions and from there emerged the new horizons of Corporate Governance and its implementation in an organization. The collapse of Enron was not the only one of its kind, but there emerged another anomaly which created a state of havoc in the Asian region and became famous enough to be called as The Enron of Asia and it was Satyam Computer Services, a Hyderabad India based company. The early 2000s was scandalous with regards to corporate governance. The world witnessed episodes of huge Corporate Scams at the hands of CEO's and Board of Directors (BOD). With an increasing number of corporate scandals there was an increased need for resolving information asymmetry (one of the prime tools used by insiders to flip the corporate resources towards personal motives). Corporate Governance mechanisms evolved for the purpose of monitoring and controlling corporate actions/transactions and to resolve information asymmetry. Among the many scandals of early 2000s, Enron, WorldCom, Tyco, Parmalat, Adelphia and a few others got careful attention from investors around the globe. There were lessons to be learnt from these series of corporate scandals. At least the need for a stable and resilient governance mechanism was realized. How to develop such a governance mechanism was a matter of research, discussion and debate.

In this study it is proposed that the prevailing evolutionary development of Corporate Governance is the best suited method towards stable and standardized Corporate Governance practices. This evolutionary development would ensure the inclusion of emerging factors into the Corporate Governance framework, thereby maintaining its relevancy and effectiveness to the present time.

At the base of Corporate Governance lies the Principal Agent Theory i.e. the separation of ownership and control. Ownership rests with the shareholders and control is entrusted with the Board and management. Humans being REMM (Resourceful, evaluative and money maximizing) according to Jensen \& Meckling 1976 would naturally tend to pursue their very own economic and social goals. This dominant self-concern of managers/controllers would deviate them from their fiduciary responsibilities as (fair) agents. Agents being responsible for the operations of corporation have an information advantage. They have the up to date knowledge of corporation's standing within the 
industry as well as the overall external environment. Agents are experienced in analyzing and evaluating the industry and thereby making effective decisions with regards to corporation's survival and growth. Whereas the owners, traditionally speaking are most concerned with the return on their investment. They do not have operational information and are not in a position to make fair evaluation of corporation's success and future prospects. In many instances of these corporate scandals lies the root cause of information asymmetry between principal and agents. A Corporation would suffer in terms of performance, efficiency and Governance if the gap between the principal's and agent's interest is huge. Sound Corporate Governance would align these divergent interests of principals and agents thereby increasing efficiency of the firm.

This paper unfolds Satyam Computer Services Ltd. Corporate Scandal of inflated financial health, the aroused concerns of investors about the effectiveness of Corporate Governance framework in India, the long term effects over Indian stock market resulting from Satyam's scam and several suggestions from the Corporate Governance theory and practice that could have helped in preventing this debacle.

\subsection{History}

It all started in the 1980s, this was the rise or one can say the boom in the IT sector of the Indian Industry. Many Indian IT firms emerged as a result of rapid growth of Information Technology. Due to adequate efforts from the Indian government the industry flourished and the IT companies began to expand globally. Bangalore became the IT hub of the country, soon India became a favorite place for the west for their outsourcing needs. As a result a large number of customers were served and Indian IT industry became the largest software and services exporter in the region. In the wake of this boom Satyam Computer Services Ltd was established in 1987 by Mr. Ramalinga Raju. The firm took a fresh start with having only 20 employees and grew rapidly over the period and became a globally recognized entity. Before its end, the number of business associates was 13,120 serving 300 customers worldwide. Satyam was engaged in IT and delivered business process outsourcing services that covered various sectors in the business environment. This endeavor made Satyam the rising star of India and strived to become an example of India's growing success [1].

\subsection{The Great Fall}

Satyam received an award "The Global Peacock" for imparting excellence in corporate and governance accountability in September 2008 but soon after five months of this award the words were in the air that the company is caught up in a big accounting fraud [2]. It was all made clear when Satyam's founder confessed to have been involved in the scam of 7800 crores. It was stated that Mr. Ramalinga had been falsifying the financials of the company and over stated the figures to misguide the shareholders, (Ahmad et al.[3]). Mr. Ramalinga confessed that fake employee accounts were created and salaries were moved into fake employee accounts, (Ramachadran [4]). After the scam the role of the external auditing firm was a big point to ponder. Therefore the company brought into investigation for their alleged involvement in the scam, (Timmons \& Wassener [5]). Investors had lost over a billion dollars in the scam. The share prices dropped more than $70 \%$ creating huge losses for the investors (Bhasin [1]).

\subsection{Reason}

The reason behind this scam was the failure to adhere to the corporate governance rules and regulations. Therefore all the rules of corporate governance were knowingly violated [25]. Becoming an example of following poor Corporate Governance. The company failed to establish a sound relationship with the employees and the shareholders. Moreover non-fulfillment of obligation towards various stakeholders arose the corporate governance issue at Satyam [1]. Some of the obligations were, failure to distinguish the roles and duties of management and the board, CEO duality i-e the chairman and CEO of company used to be the same person, absence of compensation committee, Absence of nomination committee, no measures were taken for shareholders' protection.

\section{Literature Review}

A wave of corporate frauds started across United States during early 1990s, and Enron became the most prominent example of such corporate frauds. During the nine year period from 1981 to 1989 , Jeffords critically inspected 910 cases pertaining to corporate embezzlement which were placed with the Internal Auditor, for the purpose of assessing the risk factors of specific nature which were mentioned in the report of the Treadway Commission [6]. The report concluded that the $63 \%$ approx. cases from the total of 910 cases were categorized under the head of risks associated with internal control. Moreover, Smith [7] presented in his study the specific type of typology of the individuals who commit fraud. Smith stated that people who embezzled were of "opportunist type", they instantly saw a weakness in the system and managed to seize the opportunity according to their own personal use that lead to fraudulent activity. Similarly Zeigenfuss [8] carried out a study, which was focused on the determination of the amount and type of frauds that used to occur in local and state administrations. The study concluded that more frequent of all frauds taking place were false statement of assets, under/over invoicing, theft [8].

On the other hand, Haugen and Selin [9] carried out a study in which they had argued the significance of internal controls that rely mostly on the management and the accessibility of the technology, leading to the provision of 
the required assistance in committing the fraud [9]. Sharma and Brahma [10] focused on the involvement of banks into the frauds. They said that bank frauds could be of various types. Major type of cause for execution of fraudulent activity is carelessness in observing the prevailing systems followed by procedures and actions supervised by competent authority (S. Sharma). Harris and William studied the possible motives for credit scams in financial institutions like banks (Bhasin [20]). Moreover Beirstaker et al.[24], suggested several fraud scrutiny and detection methods in their study.

Moreover Bhasin [20] did a study on instrument frauds, the amount of scams in Indian financial institutions including banks and the way in which the capabilities of the internal auditors were combined for the purpose of detecting and preventing frauds in banks by taking preemptive measures to fight fraudulent acts [20]. Chen [21] stated in a research the influence of unethical management in corporations and makes comparison of the roles of unethical leaders under different situations and diverse circumstances. With the help of computerized simulation models, Chen in a study, explained some of the factors that contributed in most of the prominent financial crimes and these factors include, how a combination of CEO's vanity, financial perks, stakeholders' hopes, expectations of the shareholders and silence of the subordinates along with dishonesty of CEO [21]. In a research conducted by Cecchini [22] and others, the researchers developed a technique for discovering corporate frauds from management's perspective using simple financial figures which were totally based upon support vector mechanisms [22].

It is evident from the above writings that majority of the studies have been carried out in developed or western countries. However, the critical role of internal audit department in referencing, verifying and cross checking the financial information with collaboration of the Corporate Governance department has been completely unexplored. What concerns me is that the 6000 fake employee generation could have been spotted earlier if the bridge between internal audit and the corporate governance was strong.

Satyam Computer Services Ltd. was among the top five companies in the Indian outsourced IT services industry. The company was formed in 1987 in Hyderabad, India by B. Ramalinga Raju. Raju was the founder and CEO of Satyam which offered Information Technology (IT) and Business process outsourcing (BPO) services to various industrial sectors globally. Satyam over a period of years established a good repute in the local and foreign market which attracted investor's attention. Satyam's sales grew tremendously from 2003 - 2008 (USD $\$ 467$ million in total sales). During this period Satyam had an annual compound growth rate of $35 \%$; average operating income was around $21 \%$ with EPS growing from $\$ 0.12$ to $\$ 0.62$, at a compound annual growth rate of $40 \%$. In 2003 Satyam's share price was Rs. 138 and by 2008 Satyam demonstrated a tremendous increase in its share price i.e. $300 \%$ with the share price rising up to Rs. 526.25 .
This extraordinary growth demonstrated by Satyam (reflected through its financial statements) was sure to attract Investors all around the world. Satyam became one of the leading IT services firm in the global IT market. The firm earned a repute of trustable, successful and growth oriented entity until January 2009, when SEC of India received a letter from the CEO Raju Ramalinga, resigning from his position in lieu of a huge scam on his part. Some termed this as India's Enron.

Satyam scam has not only put Satyam in trouble but its repercussions to Indian economy and especially to the outsourced business industry in India are un-countable. It has put a Question mark to the corporate governance practices in India. Foreign companies would be a lot more careful in their contracts with Indian companies. They might ask for certain enhanced disclosures before entering into any contracts. This is not at all a smooth situation for Indian corporations and has given a serious dent to Indian economy. Indian index fell nearly $7 \%$ on the day the Satyam news broke out (BBC NEWS, 2009). It has also put doubts about the role of auditors in India, as Hitesh Agrawal, head of research with Angel Broking says, Satyam has put doubts not only on the Indian Corporate Governance standards but has casted doubts about the fair and independent role of auditors.

The effects of Satyam scam rippled far from the local environment. Companies like Merrill Lynch, Credit Suisse and many others suspended their transactions/contracts with Satyam. PricewaterhouseCoopers authenticity was damaged and was a chance to cancel its operating license. Ironically Satyam was the winner of the Golden Peacock Award for good Corporate Governance practices, SAP Pinnacle Award. E\&Y Entrepreneur Award before the scam; all of these were ripped from the firm's account right after the debacle.

The sufferers of Satyam's criminal act were not limited to the company itself. The biggest loss was the Nation's loss of trust and credibility in the eyes of foreign investors. Among others were the employees who suffered from financial, social and emotional damage. Following the debacle was a series of layoffs, nonpayment of salaries and other benefits which caused pain for the loyal employees of Satyam. Yet among many others were the clients, shareholders (owners) and lenders. They all suffered at the hands of Ramalinga Raju's malpractice.

A few notable issues which lie beneath Satyam's debacle were:

- The Board of Directors were clearly lagging in their financial expertise. Form $20-\mathrm{F}$ filed by the firm in 2008 highlights the issue of lack of 'Audit Committee Financial Expert', which was an important requirement from the Securities and Exchange Commission.

- The choice of directors serving on Satyam's board was not remarkable. Four of the six members on the board were purely academicians and had a lack of industrial experience and practical knowledge required for proper stewardship. Two of the directors were over-occupied being serving on eight other 
company boards.

- $\quad$ Sarbanes Oxley Act (SOX) and corporate governance principles prohibits directors of having any direct involvement in firms operations. However, in Satyam's case many of the directors were participating in the operations of the company as well.

- Satyam's Form 20-F filed in August 2008 states "We do not have a Nominating/Corporate Governance Committee." This, too, is a glaring departure from "best practices" in global Corporate Governance.

- The role of auditors who authenticated Satyam's accounts is surely questionable.

- Performance awards like golden peacock award for best corporate governance practices by no means guarantee sound practices in reality. There may be criminal acts undercover like in the case of Satyam.

- Having auditing services from top ranked auditors/auditing companies do not guarantee avoidance of breach of contract.

- The absolute power of majority shareholders would overshadow the concerns and voices of minority shareholders and thus prevent their active participation/vigilance in the firm's affairs.

- The Board members had significant relationships with Satyam Corporation and its

- Management, which may have contributed to their failure to be more proactive in

- their oversight.

- In Satyam's case the Board was unduly reliant on auditors. Excess of this reliance and trust on the auditors prevented Board to be proactive and staying vigilant. Within reasonable and appropriate limits reliance on auditors and management is desirable. Beyond reasonable limits this reliance can pose serious issues.

Referring to the earlier discussion of agency problem. Due to information asymmetry and specific operational information required for performing their fiduciary duties of control and management, managers tend to have an upper hand in controlling the firm, either aligned with the shareholders interest or towards their very own personal interests. Acting independently of shareholders' interest, managers may then engage in self-interested behavior and inappropriate allocation of firm funds may occur.

Prior to 1980 's there was no mechanism to convince managers to take shareholders' interests as their primary responsibility i.e. aligning managers interests with the owners interests. One of the popular ways of aligning the interests of managers with the shareholders' interests is to tame them with the compensation mechanisms tied with the stock value. This would motivate the managers to maximize their wealth through excellent performance and this in turn would maximize owner's wealth. Stock options help to align interests because it creates incentive for the manager to increase the stock price of the firm, which consequently increases the value of his options when (if) he chooses to exercise them.
Another form of an incentive contract that helps to align the interests of shareholders and managers is to remove the manager from office if the firm income is too low (Jensen and Meckling, 1976). These innovative executive compensation mechanisms would align the interests of managers with the shareholders and would make them (fair) agents.

Institutional investors and block holders exercise good power in controlling agency problem. They have both a general interest in profit maximization, and enough control over the assets of the firm to have their interests respected," (shleifer \& Vishny, 1996). Due to this power we have witnessed an increasing number of institutional investors and block holders these days. There was also the increasing trend of having outside directors, as well as directors' equity compensation as a percentage of their total director compensation.

What follows now is the analysis of the prevailing Corporate Governance practices in India. As a startup it is important to understand what actually Good Corporate Governance is. It is a firm's perseverance in following the ethical and recommended business practices in all of its dealings with stakeholders. A firm in the line of Good Corporate Governance would not be hesitant in making required public disclosures based on fair and truthful facts and figures. Good Corporate Governance is a self-imposed strategy. It is hard to follow in letter and spirit but the long term pay backs are definitely worth it.

Of all the shortcomings in Indian Corporate Governance framework, the strongest was the lack of strong and stable oversight and monitoring mechanisms. This is typically what happened in Satyam's case. Had the board was more vigilant and proactive; Satyam's forgery with the balance sheet would have been detected much earlier than 2009 .

Satyam's debacle would have been prevented if the board committees including the audit committee were independent and fully empowered. In Satyam's case CEO Raju Ramalinga and the chairman of the Board were brothers i.e. control was in the hand of the same family. There is a need to segregate the two positions. Selection should be independent and based on competence. There was a severe lack of objective measurement of firm's performance. Satyam's entire performance was on papers. The ground reality should be an essential part of objective performance measurement. There is a need for devising mechanisms for improving the oversight of internal and external auditors. Auditors should be independent and competent. Audit committee members must be rotated frequently in order that the auditors do not develop a personal connection with the firms and their executives beyond what is essentially needed.

\section{Methodology}

Building into a brand, with just 20 employees which later crossed thousands in numbers, takes a great deal of commitment towards professionalism and strong ties with 
the industry players. Satyam Computers Ltd did an extra-ordinary effort to be named as a brand "Satyam". During the early days of its glory, Satyam was known to be the rising star of the Indian IT industry and was fearless until the day when its founder's actions burnt it down to the ground.

Let us first discuss some positive points that the company had, which helped in making to the top and gaining trust of the investors:

Satyam computer services Ltd started with only 20 employees and in just a matter of time it started to make it up to the top and began to be called the rising star of India. Its birth dates back to 1987 in Hyderabad, India.

In 2003, Satyam managed to get a contract in which it started providing IT support services to The World Bank and later in 2005 it managed to secure third position in a survey lead by Global Institutional Investor and secured third rank in best corporate governance [11]. Being a crown jewel of India and serving high profile business customers around the world the company won golden peacock award for being one of the best companies governed between the year 2007-2009,[23]. From 2003-2008, the company outperformed in the relevant industry and the financial performance of the company boosted the investor confidence in all respects. The company overall managed to generate sales of $\$ 467$ million. And by the end of March 2008 the company worth increased to a total of $\$ 2.1$ billion. This brought an increasing trend in the company's EPS and rose the gross margins and the share prices topped by $300 \%$ high, (the pioneer [12]). Bhasin [20] stated in his paper that due to high level of technical expertise the company had a total of 13,120 technical associates that were efficient enough to serving 300 high profile customers around the world (the pioneer [12]).

Some negative facts about the company:

There's been an insider trading within the organization. According to the joint investigation conducted by the CID and State Agencies, published in (the hindu [13]), the Promoters were responsible for the insider trading within the company resulting in the pooling of the company's shares into buying large amounts of land units. Mr. Raju the founder, his brother and relatives used the funds to purchase land in the names of 330 companies out of which 327 belonged to Mr. Raju's family. The company had no governance structure to curtail such kind of act.

There was another weakness of company's management and it was the failure to provide transparent and ethical disclosure of the financial information to the shareholders. The top management of the company deliberately falsified the company's financials. According to the investigation report the information regarding the fixed assets was tampered. The management showed the wrong figures stating the fixed assets to be about Rs 3318.37 crore while actually the figure was only Rs 9.96 crores [12].
Moreover the board of directors was composed of members that were chairman friendly. They never ever questioned the chairman about his plans, strategies and maneuvers that ultimately led to a fraud. The board ignored Mr. Raju's wrong doings and failed to perform their duties. They simply allowed the fraud to happen. Such kind of weakness cannot be tolerated when it comes to giant corporate. A strong and transparent audit committee is very crucial in an organization. In Satyam, the audit committee was not transparent. Even after the word from a whistleblower, the warning and tip to the ongoing fraud was left for granted. Such kind of weak and non-transparent audit committee is a weakness to the company [11].

Satyam computers was not alone in the battlefield, it had competitors too. And prominent were Wipro and Infosys.

\subsection{Wipro: A Brief Review}

Wipro was known to be the global Indian company that served in IT services industry. The company was engaged in making hardware, provides outsourcing services to the global corporations that included software app development, business process integration, IT solutions, Data sourcing. Other than these services, Wipro also provided assistance in R\&D services to various international organizations. Headquartered in Bangalore, revenues of Wipro increased by $43 \%$ than previous year in the June quarter. Revenues and profits increased by the rate of $5 \%$ and $3 \%$ respectively. "We are expecting lots of uncertainty and we'll try our level best to remain careful in the future ahead" said by Mr. Amiz Premji, Chairman Wipro. By the end of third quarter 2008, Wipro expected revenues to gross around $\$ 1.09$ billion from IT business services (Rs4,665 crore), second quarter growth was around $2 \%$, making $\$ 1.07$ billion for the year 2008 [14].

\subsection{Infosys: A Brief Review}

Infosys Technologies Limited was another Indian player in the IT sector of India competing next to Satyam and many others. The company was formed in 1981 by Mr. Narayana Murthy and six other engineers at that time with an initial investment of $\$ 250$ and by the end of 2008 it began to raise around $\$ 4$ billion in sales revenue for the company (Fareeda [15]).

Besides software development, Infosys also dealt in the provision of consultation services in IT and business processing to the worldwide customers.

According to the Exhibit I, it becomes clear to have a look at the financial performance of Infosys year by year. This reflected company's consistent growth in the income level over the years and was only possible due to having sound business strategies and trust of the investors and customers. By looking at the exhibit it becomes quite certain that the company was good in their business practices and consists a transparent corporate governance culture, where every disclosure was a transparent one. 
Exhibit I. The Financial Performance of Infosys during 2000-2008 (INR crore)

\begin{tabular}{|c|c|c|c|c|c|c|c|c|c|c|}
\hline & \multicolumn{2}{c}{ Rs } & \multicolumn{2}{c}{ Rs } & \multicolumn{2}{c}{ Rs } & \multicolumn{2}{c}{ Rs } & Rs & \multicolumn{2}{c}{ Rs } & \multicolumn{4}{c|}{ Rs } & Rs \\
\hline Details & 2000 & 2001 & 2002 & 2003 & 2004 & 2005 & 2006 & 2007 & 2008 \\
\hline Income & 921 & 1901 & 2604 & 3626 & 4761 & 6860 & 9028 & 13149 & 15648 \\
\hline Operating Profit (PBIDTA) & 378.88 & 765 & 1038 & 1272 & 1584 & 2325 & 2989 & 4225 & 4963 \\
\hline Profit After Tax (PAT) & 293.52 & 628.81 & 807.96 & 958 & 1234 & 1904 & 2421 & 3783 & 4470 \\
\hline EPS (par value of INR 5 each) & 43.23 & 94.23 & 122.12 & 144.63 & 46.84 & 69.26 & 88.67 & 67.82 & 78.24 \\
\hline P/E Ratio (times) & & 36.57 & 25.44 & 21.28 & 26.35 & 32.59 & 33.62 & 29.76 & 18.40 \\
\hline
\end{tabular}

Source: Infosys Annual Reports (2000-2008)

Satyam Computers, though started from a small level managed to get a sales revenue of about $\$ 2$ billion by the end of 2008 . And it's a really big thing to make a \$2 billion mark within considerable less time period as compared to Infosys or Wipro. Satyam managed to get the place by using multi-pronged business strategy. Due to this it expanded into a variety of IT related businesses which gave the company a competitive edge and significant presence in a number of business areas around the globe.

Exhibit II. Satyam's Financial Performance over a Decade (INR crore) Rs.

\begin{tabular}{|c|c|c|c|c|c|c|c|c|c|c|}
\hline \multicolumn{2}{c}{ Rs } & \multicolumn{1}{c}{ Rs } & \multicolumn{1}{c}{ Rs } & Rs & Rs & Rs & \multicolumn{2}{c|}{ Rs } & \multicolumn{2}{c|}{ Rs } \\
\hline Particulars & 2000 & 2001 & 2002 & 2003 & 2004 & 2005 & 2006 & 2007 & 2008 \\
\hline Total Income & 679.01 & $1,241.67$ & $1,803.10$ & $2,051.51$ & $2,623.28$ & $3,546.78$ & $5,012.22$ & $6,410.08$ & $8,394.48$ \\
Operating Profit (PBDIT) & 252.56 & 466.71 & 652.32 & 646.39 & 774.31 & 971.70 & $1,571.42$ & $1,710.73$ & $2,085.74$ \\
Profit after tax & 134.86 & 316.16 & 490.13 & 459.88 & 555.79 & 750.26 & $1,236.75$ & $1,423.23$ & $1,715.74$ \\
EPS & 2.45 & 5.26 & 7.89 & 7.31 & 8.82 & 11.81 & 19.26 & 21.73 & 25.66 \\
P/E ratio (times) & & 20.81 & 16.96 & 12.10 & 16.64 & 17.32 & 26.43 & 21.64 & 15.88 \\
\hline
\end{tabular}

Source: Satyam Annual Reports (2000-2008)

In Exhibit II it is clear to see the timeline of financial performance of Satyam up till 2008 and it is clear that Satyam was on the road destined for success. The whole thing blew up when the scam in the company went viral and was found that the CEO and $\mathrm{CFO}$ were presenting a complete window dressed version of the financial statements to the investors since long.

The scam was later on confessed by Mr. Raju by writing a letter to the Board [15].

The news of the scam spread like a fire in the jungle and overnight the share price of Satyam took a hard hit. The share price that once was more than Rs 200 fell to Rs 39.95 by the end of January 7, 2009 and later fell to Rs 11.50 by the end of January 10, 2009. (business Standard [16]; Gunta \& Ravichandran [17] ; H. Timmons and B. Wassener [18]; ibnlive [19]).

Exhibit III. (fall from Grace) gives a bird's eye view of the periodic changes in the Satyam's share price over the years.

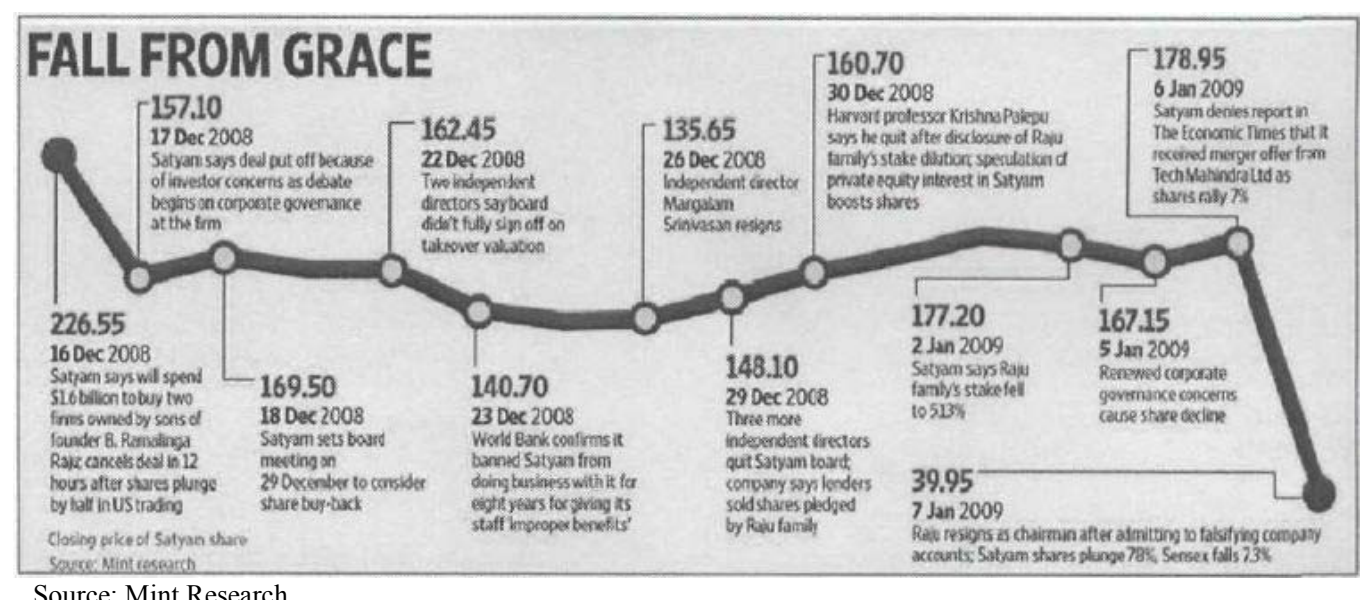

The fraud saga began by an adjustment of $\$ 100$ million which was then overstated as $\$ 1000$ million in the books. Ever since, Mr. Raju and CFO of the company presented fabricated accounting records to overstate the actual figures. The assets were overstated and the liabilities were understated. The details under makes it very clear [1]). 
Fabricated Financial Statement of Satyam, Sep 2008

\begin{tabular}{cccc}
\hline Items Rs. in crore & Actual & Reported & Difference \\
\hline Cash and Bank Balances & Rs & Rs & Rs \\
& 321 & 5361 & 5040 \\
Accrued Interest on Bank & Nil & 376.5 & 376 \\
Fixed Deposits & & & \\
Understated Liability & 1230 & None & 1230 \\
Overstated Debtors & 2161 & 2651 & 490 \\
Total & Nil & Nil & 7136 \\
Revenues (Q2 FY 2009) & 2112 & 2700 & 588 \\
Operating Profits & 61 & 649 & 588 \\
\hline
\end{tabular}

Mr. Ramalinga Raju along with his CFO created 6000 fake employee IDs and from there he managed to get withdraw the sum of money pertaining to those fake employee accounts and the amount was then used to falsify the balance sheet figures [20].

\section{Conclusions}

Strong financials are considered to be the key resources for an organization. Lower cost of debt and stable financial position of a company helps a lot in outperforming the industry peers. This helps a company to form a strong base or a foundation to withstand the decisions made by the management. So, there is a need for an effective framework that regulates and cross checks the financial activities of the firm. In Satyam, the corporate governance structure was excellent apparently but actually it was not in line with the financial goals of the company. The corporate governance structure failed to initiate the protocols regarding financial setbacks and created a loophole that ultimately lead to a disaster. The persons responsible for corporate governance failed to make a strong link with both the internal audit department and internal audit committee which resulted in a bond developed between CEO and CFO to present window dressed financial statements to the stakeholders. Transparent and ethical disclosure of information is among top priorities of the management and Satyam's management failed to do that. Such kind of scams cannot be stopped, but the risk could be minimized by creating barriers set by an efficient management that creates an effective corporate governance structure.

\section{Recommendations}

It is proposed that corporations must uplift the moral, ethical and social values of its executives. There needs to be a living conscience with company executives that will serve as a guidepost in the best and worst circumstances.

Secondly, board members need to feel the importance of the responsibility entrusted with them. They need to be proactive and watchful in protecting the interests of owners. There was a lack of proper and timely information in
Satyam's case. Board members need to be careful with regards to the communication of information within the firm as well as towards the owners. Fair and accurate information would be extremely valuable in minimizing information asymmetry and agency problem.

Thirdly, shareholder activism is an excellent mechanism of keeping a check on the corporation and its executives. Shareholder Activism then again would be effective if the disclosures made by corporation are accurate, valid and according to the laid down policies and principles of Corporate Governance. The strong power of 'voting by feet' is sufficient to voice against the acts of firm and its members. Blockholders and institutional investors can also serve as an effective means for board's and management's accountability.

From the study it may be concluded that effective Corporate Governance is an integrated all round performance by the stakeholders. Human nature is of selfishness, greed and self-interest. People who are looking for the protection of their interests need to stay vigilant and watchful and utilize the existing mechanisms no matter how bleak they are. If there is an increased activism around these multi-billion corporations, they would not violate or by pass owners interest so easily and get away just like that. Strong board oversight and shareholder activism are the key to protect owners interests. Corporate governance framework needs to be implemented in letter as well as spirit. The increasing rates of white collar crimes demands stiff penalties and punishment. Above everything, there needs to be an increased awareness of shareholders about their rights and privileges.

\section{REFERENCES}

[1] Bhasin, Madan Lal. (2013). Corporate Accounting Fraud: A Case Study of Satyam Computers Limited. Open Journal of Accounting, 2, 26-38.

[2] Basilico, Elisabetta, Grove, Hugh, \& Patelli, Lorenzo. (2012). Asia's Enron: Satyam (Sanskrit Word for Truth). Journal of Forensic \& Investigative Accounting, 4(2).

[3] Ahmad, Tabrez, Tabrez, Malawat, Kochar, Yashovardhan, \& Roy, Ayan. (2010). Satyam Scam in the Contemporary corporate world: A case study in Indian Perspective. IUP Journal.

[4] Ramachadran, S. (2009). Raju brings down Satyam, shakes India. Asia Times Online Ltd.

[5] Timmons, H. and B. Wassener. (2009). Satyam Chief Admits Huge Fraud, 2014, from www.nytimes.com

[6] Jeffords, R, Marchant, ML, \& Bridenall, PH. (1992). How useful are the treadway risk factors? Internal Auditor, 49(3).

[7] Smith, ER. (1995). A positive approach to dealing with embezzlement. The White Paper, 17-18.

[8] Zeigenfuss, Douglas E. (1996). State and local government fraud survey for 1995. Managerial Auditing Journal, 11(9), 
$50-55$.

[9] Haugen, Susan, \& Selin, J Roger. (1999). Identifying and controlling computer crime and employee fraud. Industrial Management \& Data Systems, 99(8), 340-344.

[10] Sharma, S. Brahma (2000) A Role of Insider in banking Fraud. available at http. manuputra. com.

[11] SHARMA, JP. WHAT WENT WRONG WITH SATYAM?

[12] the pioneer. (2009). What Went Wrong With Satyam, 2014, from http://www.dailypioneer.com/

[13] the hindu. (2009). KPMG cannot restate Satyam accounts, says ICAI, 2014, from http://www.thehindu.com/todays-pap $\mathrm{er} / \mathrm{tp}$-business/kpmg-cannot-restate-satyam-accounts-says-ic ai/article344430.ece

[14] livemint. (2008). Wipro, Satyam profits rise, but markets are still not impressed, 2014, from http://www.livemint.com/Mo ney/ysFzwX5NTdtP6dSWnVoM3H/Wipro-Satyam-profits-r ise-but-markets-are-still-not-impres.html

[15] Fareeda, D. Satish. (2012). Infosys and Satyam Computers: Whose Wealth is Maximised?

[16] business Standard. (2009). Satyam investors lose over 13,000 $\mathrm{cr}$ in a month, 2014, from http://www.business-standard.com /india/ storypage.php?autono $=52584 \& \mathrm{tp}=\mathrm{on}$

[17] Gunta, Srinivas, \& Ravichandran, N. Exhibit 5: Performance of Infosys over the years.
[18] Timmons, Heather, \& Wassener, Bettina. (2009). Satyam chief admits huge fraud. New York Times, 8.

[19] ibnlive. (2009). Satyam shocker: Mkts 749 pts down as investors panic, 2014, from http://ibnlive.in.com/news/satya m-shocker-mkts-749-pts-downas-investors-panic/82172-16.html

[20] Bhasin, M.L. (2008). Corporate Governance and Role of the Forensic Accountant. The Chartered Secretary Journal, 38(10), 1361-1368.

[21] Chen, Stephen. (2010). The role of ethical leadership versus institutional constraints: A simulation study of financial misreporting by CEOs. Journal of Business Ethics, 93(1), 33-52.

[22] Times of India. (2009, december 8). What Went Wrong With Satyam.

[23] Bierstaker, James L, Brody, Richard G, \& Pacini, Carl. (2006). Accountants' perceptions regarding fraud detection and prevention methods. Managerial Auditing Journal, 21(5), 520-535.

[24] Chakrabarti, Rajesh, Megginson, William, \& Yadav, Pradeep K. (2008). Corporate governance in India. Journal of Applied Corporate Finance, 20(1), 59-72. 